preparation was especially noticeable; some of his specimens, skinned more than thirty years ago, are as neat in appearance and as fresh as the day they were prepared. Returning in 1840, after two years' absence, he commenced the great work on the "Birds of Australia," which makes seven folio volumes and occupied seven years in its production, being completed in 1848 . One of the features of this work is the great increase in our knowledge of the range and habits of petrels and other seabirds, to which the author paid great attention during his travels.

Within a year of Mr. Gould's return from his adventurous voyage he had the misfortune to lose his wife, and for some time he was completely overwhelmed by his bereavement. His collectors in Australia too, about the same period, lost their lives; one of them, Mr. Gilbert, was killed during Dr. Leichhardt's expedition overland from Moreton Bay to Port Essington, and Mr. Drummond, while collecting in Western Australia, was also murdered by natives, and a third collector was killed by the explosion of a gun on one of the islands of Bass's Straits. It speaks volumes however for the zeal and energy with which Mr. Gould had prosecuted his researches in the Australian continent that very few birds, sufficient only to form a supplement in a single folio volume, have been discovered since he left the field of his labours in that quarter of the globe.

Another landmark in the career of this great ornithologist was the publication of his Monograph of the Trochilidæ, or Family of Humming Birds. These lovely little birds had been for a long time favourites with Mr. Gould, who gradually began to amass that fine collection which has been the admiration of naturalists for so many years. Taking advantage of the Great Exhibition of 1851 , he obtained permission from the Zoological Society to erect at his own cost a large building in their gardens in the Regent's Park, where the collection was open to the public at a charge of sixpence per head. A considerable sum was realised by this exhibition, and a large number of subscribers to his monograph was obtained, including nearly all the royal families of Europe. Though sketched by Mr. Gould himself (for even to the last days of his life he executed the designs for all his plates), the majority of the humming-birds were placed on stone by Mr. Richter, who also did the same for Mr. Gould's next work, "The Birds of Asia." We cannot but regard this as one of the most valuable of all the works done by the author, for, notwithstanding the fact that it is left unfinished at his death, it contains a large number of plates of species not eIsewhere figured. The "Mammals of Australia," produced simultaneously with the last-mentioned work, deserved, in Mr. Gould's own opinion, more credit for its issue than perhaps any work he had done, because it touched upon a branch of zoology of which he never pretended to have a very exact knowledge. So large however had been his collections of mammalia during his sojourn in Australia that some account of them seemed to be demanded, and he therefore published his large folio work; but the pecuniary results were less satisfactory than with any of his ornithological productions. His typical specimens of the Australian mammalia are in the national collection. No sooner were the humming-birds finished than his active brain conceived a new idea, to illustrate becomingly the birds of his native land, and he commenced the publication of the "Birds of Great Britain." Opinions may differ as to the merit of Mr. Gould's other works; volumes less ponderous than the folios which he adopted for the better figuring of the objects of the natural size, may take their place with the student; but no work of greater beauty will be produced than that on which John Gould, returning in his later life to his first love, bestowed the fulness of his energy and the acme of his artistic talent. The care bestowed on the plates of this work was remarkable, the aim of the author being to produce a picture of the birds as they appeared in their natural haunts, and especial pains were bestowed on the young, particularly those of the wading-birds and natatores. In this fine work most of the drawings were developed and placed on stone by Mr. W. Hart, who also executed all the plates of the later works.

In $1865 \mathrm{Mr}$. Gould republished his letterpress of the big work in an octavo form, under the title of "A Handbook to the Birds of Australia," but with all the additional species inserted in their proper families; these two volumes are therefore of great use to the student. After the completion of his work on "British Birds," Mr. Gould devoted himself to the continuation of the "Birds of Asia" and the Supplement to the "Birds of Australia," until in 1875 he commenced a work on the "Birds of New Guinea," which was to contain also descriptions of any new species to be discovered in Australia or any part of the Australian region. Of the last-named work eleven parts have appeared, and it was left unfinished at his death, as well as the following works :- a "Monograph of the Pittidæ or Ant-Thrushes of the Old World" (one part published), the Supplement to the "Monograph of the Hunming Birds" (two parts published), and the "Birds of Asia."

The above list enumerates, we believe, nearly all the works published by Mr. Gould with the exception of the "I cones Avium," issued about 1838, and containing supplementary plates to his previous volumes, with descriptions of new species, and the "Monograph of the Odontophorhinæ or Partridges of America." In addition to the folio volumes he was also in the habit of publishing the introductions to his larger works in an octavo form.

Many of the above details of Mr. Gould's life are taken from "Men of Eminence," aided by the personal recollections of the writer, who was for many years an intimate friend of the deceased, and knew him first as a successful trout-catcher on the Thames, for his prowess in throwing the fly was scarcely second to his skill as an artist. Were he to write an epitaph of John Gould he would do so in the words which Mr. Gould himself was fond of quoting:- "Here lies John Gould, the Bird-Man." The latter words were used by an old and intimate friend in introducing $\mathrm{Mr}$. Gould to another relative. We may hope that the Government, according to the well-known wishes of the deceased naturalist, will allow no false motives of economy to interfere with the purchase of $\mathrm{Mr}$. Gould's collection of birds for the British Museum, and that the disgraceful spectacle of his Australian collection (unrivalled to this day, and offered to the nation for the small sum of $1000 \%$.) being allowed to leave the country, may not be repeated.

\section{THE BLACKHEATH HOLES}

$T \mathrm{HE}$ chalk forming the base of the escarpment between Woolwich and the entrance to the valley of the Ravensbourne, dips at a low angle to the south-south-east under Greenwich Park and Blackheath, where it is overlaid by the Thanet Sands, estimated by Mr. Whitaker of the Geological Survey at 40 to 50 feet, the Reading and Woolwich Beds, consisting of shelly clays, sometimes 40 feet thick, associated near Lewisham with fine laminated sands. These beds are overlain by the Oldhaven or Blackheath gravels, reaching a thickness of about 50 feet, which have been largely dug for gravel in various parts of the district.

In the centre of this tract at Blackheath, on the west side of the angle of the roads from Greenwich Park to Blackheath Station, and from the Park to the Paragon, appeared in the early morning of Thursday, April 12, 1878, a subsidence near the row known as Rotten Row, referred to in these columns at the time, the hole being 8 or 9 yards in circumference. In November, 1880, appeared another hole near the gravel pit below Eliot Place 
and Heath House, and about 550 yards south-west of the first hole; and still later in that month, on the roth, a third subsidence made its appearance, this time about IOO yards to the south-east of the first subsidence, and nearer to All Saints' Church.

The Astronomer-Royal and other inhabitants of the district being anxious to know how far other subsidences were probable, asked the Metropolitan Board of Works, who have jurisdiction over the Heath, and who had fenced in the sinkings, to investigate their cause. This however they declined to do, though giving to the Astronomer-Royal permission to do so; this authority he handed over to a newly-formed society, called the Lewisham and Blackheath Scientific Association, who formed a committee of investigation, including members of the West Kent Natural History Society, for which end subscriptions are now being sought, and operations will shortly be commenced, as announced in our columns.

The surface of the chalk is estimated by one member of the committee, Mr. T. V. Holmes, as probably occurring at about 100 feet from the surface at or about the Ordnance datum line. The investigations so far made show the third sinking to consist of an oval vertical shaft 7 feet 8 inches diameter by 6 feet 9 inches, with a depth of 18 feet, opening into a cavity extending in both directions, and partly choked with fallen earth, giving a total diameter, as far as examined, of 14 feet. . The upper part of the shaft is described by Mr. Holmes as consisting of sand and clay resting on sand, overlying pebbles, in which the cavity below is formed. The material carefully removed from the bottom of the pit is found by Mr. H. W. Jackson to be of the same material as the upper beds of the shaft, proving the sinking due to removal of material from below. The first sinking is filled up and cannot be investigated; the second is not fully examined for want of funds, but is wholly in gravel, and also extends underground in two directions.

Various theories have been suggested by different observers to account for their origin, some considering them artificial, Admiral Hamilton that they are caused by the abstraction of water caused by the maindrainage works, which tapped powerful springs in the Lower Woolwich Road; others connect their appearance with removal of chalk, and water in the chalk, by the Kent Waterworks, who lift daily about nine million gallons a day from their wells in the neighbourhood, whilst others connect them with excessive rainfalls, the first subsidence having taken place after the great floods in the Ravensbourne, caused by the rain of the night of the IIth and morning of the I2th of April, I878.

The height of the chalk water-line (Fournal, Society of Arts, 1877) at Woolwich Dockyard well is about 15 feet below the Ordnance datum line before pumping, at the Kent Waterworks, Plumpstead, $\mathrm{x}$ foot 4 inches below, but at the Kent Waterworks wells at Deptford it is pumped down to nearly 70 feet below, rising 50 feet after pumping, or about 20 feet below Ordnance datum. The surface of the chalk at Bromley, at the Shortlands pumping-station, has risen to 70 feet above the datum, the water rising after pumping to 122 feet above it. This district is on the south side of a synclinal axis ranging east-north-east through Eltham, described by Mr. Whitaker, which throws in a trough of London clay, that cuts off this supply, from the chalk water entering at the Greenwich Park escarpment.

The water-level under Blackheath is at, or about, Ordnance datum, trending south towards the London clay synclinal, corresponding, under the site of the subsidences, to the surface of the chalk beneath the Thanet sands, and if there is no great quantity of chalk above the water-level it appears improbable that the subsidences are due to pipes descending vertically into the chalk, but it is quite possible that the drainage works, removing the waters held by the pebble beds above, disturbed their stability, and caused their subsidence. On the other hand it is not impossible that drift levels may have been driven into the chalk from the ancient chalkpits a mile distant, ceasing when they reached the outcrop of the chalk against the Thanet sand, and which is immediately under the site of the subsidences.

\section{E. DE RANCE}

\section{MERCADIER'S RESEARCHES ON THE PHOTOPHONE}

$A \mathrm{~N}$ elegant series of researches in photophony have $\mathrm{A}$ lately been published by M. E. Mercadier of Paris, who has very carefully examined the phenomenon discovered by Graham Bell and Sumner Tainter, that an intermittent beam of light may generate a musical tone when it falls upon a thin disk. By way of distinguishing this phenomenon and its applications from the phenomenon of sensibility to light exhibited by annealed selenium, which constitutes the essential principle of the articulating photophone, M. Mercadier adopts the name of radiophony for the subject of his research: a name which appears moreover to have the advantage of not assuming a priori what kind of radiations, luminous, calorific, or actinic, are concerned in the production of the phenomenon. It is agreed by all who have experimented in this direction that the pitch of the note emitted by the disk corresponds precisely with the frequency of the intermittent flashes of light: but it has been disputed whether the effect is due to light or to heat. Prof. Bell found that the beam filtered through alum water to absorb the calorific ultra-red rays produced tones; and that even when a disk of thin ebonite rubber was interposed, the beam robbed of both heat-rays and light-rays could still generate tones. On the other hand, from the list of substances given by the original discoverers, it was evident that since dark and opaque substances with dull surfaces, and those which, like zinc and antimony, have high coefficients of thermal expansion, produce, cateris paribus, the best results, the effects must probably arise from heating effects due to absorption of radiations of some kind and their degradation into heat of low temperature.

M. Mercadier has summarised his results in an article in the Comptes rendus, from which the substance of this article is translated freely. The chief conclusions are as follows :-

I. Radiophony does not appear to be an effect due to the vibration of the receiving disk vibrating transversely in one mass as in an ordinary vibrating elastic plate.This conclusion appears to be justified by the following observations : that, given a thin plate of any kind, under the conditions necessary for the production of the phenomenon, it produces equally well tones of all different degrees of pitch from the lowest audible up to the highest that can be generated experimentally by optical intermissions, and which in M. Mercadier's apparatus attained to a frequency of 700 vibrations per second. Moreover it was found that these changes of pitch were accomplished without any defect in the continuity of the phenomenon; which would seem to indicate that it was not necessary for the plate to vibrate in any particular nodal or partial mode. Also the receiving disk will produce chords equally well in all possible tones from the highest to the lowest, the chord being complete no matter whether the fundamental pitch be raised or lowered by altering the speed of the rotating apparatus by which the intermittences are produced. M. Mercadier's apparatus consisted of a glass wheel carrying on its surface a paper disk pierced with four series of holes, numbering respectively $40,50,60$, and 80 . Through any one of these series of holes a small pencil of rays could be passed, and, by raising or depressing the axis of rotation of the wheel, could be sent successively through each of the four, thus 